Geographic distribution of Leguminosae the Itacolomi

\title{
Geographic distribution patterns of Leguminosae and their relevance for the conservation of the Itacolomi State Park, Minas Gerais, Brazil
}

\author{
Valquíria Ferreira Dutra ${ }^{1,2,6}$, Laura Cristina Pires Lima ${ }^{2,3}$, Flávia Cristina Pinto Garcia ${ }^{2}$, \\ Haroldo Cavalcante de Lima ${ }^{4}$ \& Ângela Lúcia Bagnatori Sartori \\ ${ }^{1}$ Universidade Federal do Espírito Santo, Departamento de Ciências Biológicas, Setor de Botânica, Av. \\ Fernando Ferrari 514, Goiabeiras, 29075-910, Vitória, ES, Brasil (www.ufes.br) \\ 2 \\ Programa de Pós-Graduação em Botânica, Universidade Federal de Viçosa, Departamento de Biologia \\ 3 Vegetal, Av. P.H. Rolfs s.n., 36570-000, Viçosa, MG, Brasil (www.ufv.br) \\ ${ }^{3}$ Universidade Estadual de Feira de Santana, Departamento de Biologia, Avenida Transnordestina s/n, \\ 44031-460, Feira de Santana, BA, Brasil (www.uefs.br) \\ Instituto de Pesquisas Jardim Botânico do Rio de Janeiro, Rua Pacheco Leão 915, 22460-030, Rio de \\ $5 \quad$ Janeiro, RJ, Brasil (www.jbrj.gov.br) \\ Universidade Federal de Mato Grosso do Sul, Laboratório de Botânica, C.P. 549, 79070- \\ 900, Campo Grande, MS, Brasil (www-nt.ufms.br) \\ 6 \\ Corresponding author: Valquíria Ferreira Dutra,e-mail: valquiria.dutra@bol.com.br
}

DUTRA, V. F.; LIMA, L. C. P.; GARCIA, F. C. P.; LIMA, H. C. AND SARTORI, A. L. B. Geographic distribution patterns of Leguminosae and their relevance for the conservation of the Itacolomi State Park, Minas Gerais, Brazil. Biota Neotropica. 14(1): e20133937. www.biotaneotropica.org.br/v14n1/en/abstract?article+bn00214012014

\begin{abstract}
This study identified patterns of geographic distribution of 102 Leguminosae taxa within the Park, based on literature data and herbarium specimens. Among the taxa, 38 grow exclusively in Campos Rupestres (rocky fields) and 49 in the Semideciduous Forest. Eleven patterns of geographic distribution were identified, of which the West-East- Central South America pattern was the most representative, with 27 taxa. Of the 102 sampled taxa of Leguminosae, five are endemic to the Espinhaço Range and ten are included in lists of endangered species of the flora of Brazil and Minas Gerais. Information on these taxa is crucial to provide conservation practices for conserving the vegetation formations of the PEIT.
\end{abstract}

Keywords: Atlantic Forest, Espinhaço Range, Fabaceae, rocky fields, Semideciduous Forest

DUTRA, V. F.; LIMA, L. C. P.; GARCIA, F. C. P.; LIMA, H. C. AND SARTORI, A. L. B. Padrões de distribuição geográfica de Leguminosae e sua importância para a conservação do Parque Estadual do Itacolomi, Minas Gerais, Brasil. Biota Neotropica. 14(1): e20133937. www.biotaneotropica.org.br/v14n1/pt/abstract?article+bn00214012014

Resumo: Neste estudo foram identificados os padrões de distribuição geográfica dos 102 táxons de Leguminosae ocorrentes no PEIT, com base nos dados obtidos na literatura e em material de herbário, sendo 38 exclusivos dos Campos Rupestres e 49 das Florestas Estacionais. Foram reconhecidos 11 padrões de distribuição geográfica, dos quais o padrão América do Sul Ocidental- Centro-Oriental foi o mais representativo com 27 táxons. Dos 102 táxons amostrados de Leguminosae, cinco são endêmicos da Cadeia do Espinhaço e 10 constam nas listas de espécies ameaçadas da flora brasileira ou da Flora de Minas Gerais, sendo consideradas importantes para fornecer subsídios na conservação das formações vegetacionais do PEIT.

Palavras-chave: Cadeia do Espinhaço, campos rupestres, Fabaceae, Florestas Estacionais, Mata Atlântica 


\section{Introduction}

Leguminosae is the third largest family of flowering plants, comprising 727 genera and 19.325 species (Lewis et al. 2005). The high ecological plasticity of the family allows its distribution in highly diverse habitats and this peculiar feature is determinant for its great diversity in neotropical vegetation types (Lima 2000). In Brazil, the family is represented by 212 genera and 2717 species (Lima et al. 2010a), distributed in almost all vegetation types (Barroso et al. 1991). Moreover, it has been identified as one of the most representative of flowering species in the Campos Rupestres (rocky fields), in the Cerrado (Brazilian savannas) and Tropical Forests (Giulietti \& Pirani 1988, Mendonça et al. 1998, Ribeiro 1998, Pirani et al. 2003, Dutra et al. 2008a), highlighting its importance for the flora of Brazil.

In floristic surveys of biomes of the state of Minas Gerais, Leguminosae has also been considered one of the most representative flowering plant families, as reported for Caatinga ( e.g. Brandão \& Gavilanes 1994), Cerrado (e.g. Brandão \& Gavilanes 1997), Campos Rupestres (Dutra et al. 2008a) and areas of Atlantic Forest (Oliveira-Filho et al. 1994). Information as this about the diversity of species, together with data on the presence of endemic, threatened and rare species, has been used to determine priority conservation areas in the State and to delimit areas which require the creation and implementation of Conservation Units (Drummond et al. 2005).

The Itacolomi State Park (PEIT) is located in the southern part of the Espinhaço Range, in the so-called Quadrilátero Ferrífero (Peron 1989), in a vegetation transition zone between the Atlantic Forest and the Cerrado, representing an important migratory corridor and consisting of gallery forests between the two formations (Oliveira-Filho \& Ratter 1995).

The vegetation of the Espinhaço Range includes a series of altitudinal strata, with Campos Rupestres and cloud forests in the highest strata, Cerrado and Semideciduous Forests in the intermediary strata and a varied combination of vegetation types of the adjacent lowlands (Harley 1995). The geological antiquity, geographical position and climate fluctuations that occurred during the Quaternary and allowed a vertical migration of the flora from the lower regions, as well as the physiognomy variety are the main factors related to the high biodiversity of the Espinhaço Range (Giulietti et al . 2002, Gontijo 2008). The high species richness, high landscape diversity and high degree of endemism led to the recognition of the Espinhaço Range as one of the priority areas for conservation, with special biological importance, hence the area of the PEIT has great biological relevance (Drummond et al. 2005).

The aim of this study was to analyze the endemism and habitat preference of the Itacolomy State Park flora using the Leguminosae family as a model to characterize geographic distribution patterns of specific and/or infraspecific taxa. The patterns that emerged from the analysis were used to answer the following questions: (i) What is the influence of the surrounding vegetation on the flora of the PEIT? (ii) What are the implications of the findings for the conservation of the flora of the park?

\section{Methods}

The PEIT is located in the municipalities of Ouro Preto and Mariana, State of Minas Gerais, (between $20^{\circ} 22^{\prime} 30^{\prime \prime}$ and

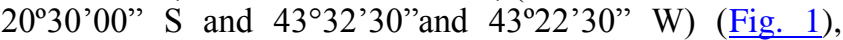
comprising the entire Itacolomi Range (Peron 1989). The Park encompasses an area of approximately 7000 ha. The relief is characterized by steep slopes and altitudes between 700 and $1772 \mathrm{~m}$ (Messias et al. 1997).

The regional climate is typically tropical, Cwa and Cwb, according to Koeppen's classification, with two welldefined seasons: a dry season, from May to September, and a rainy season, from October to April. The annual rainfall is on average $2018 \mathrm{~mm}$ (Messias et al. 1997, Nalini Junior et al. 2006). Fog is frequent and the average annual temperature is $21{ }^{\circ} \mathrm{C}$ (maximum $33{ }^{\circ} \mathrm{C}$, minimum $4{ }^{\circ} \mathrm{C}$ ) (Messias et al. 1997).

The soils were formed by the weathering of parent material, mostly of quartzite and mica-schists of the Minas Supergroup, with latosols, where the topography is hilly, and lithosols where the relief is jagged (Messias et al. 1997).

The vegetation consists of Semideciduous Forest and Campos Rupestres (Messias \& Sousa 2006, Fig. 2), varying with the soil, water availability, altitude and topography.

The Campos Rupestres practically cover the entire Park at elevations above $1000 \mathrm{~m}$. They are characterized by the diversity of substrates formed by the exposure of various types of rocks, shallow, lithic, sandy, acidic and nutrientpoor soils with limited water and intense sun exposure (Giulietti \& Pirani 1988, Meguro et al. 1994, Giulietti et al. 1997). The vegetation is formed by a well-developed herbaceous- shrub stratum and has a heterogeneous flora composed of many endemic species (Harley 1995, Mendonça et al. 1998).

The Semideciduous Forests that grow in highly seasonal parts of the tropics, with a severe and prolonged dry season, have mean annual precipitation below $1600 \mathrm{~mm}$ and 5-6 months of the year with less than $100 \mathrm{~mm}$ rainfall (Gentry 1995). Most species of these forests are deciduous, with $20-50 \%$ of the trees losing their leaves in the dry season (IBGE 2012). The Semideciduous Forest of the PEIT can be classified, by the altitudinal gradient, as submontane $(300-700 \mathrm{~m})$, lower highlands (700-1100m) and upper highlands (above 1100m) (Oliveira-Filho 2009).

The list of taxa used in this study was obtained from the floristic survey of the Leguminosae within the PEIT (Lima et al. 2007, Dutra et al. 2008b, 2008c, 2009, Lima et al. 2010c). The habit descriptions were according to GuedesBruni et al. (2002).

The mapping of the geographical distribution was based on the occurrence records of herbarium collections (BHCB, OUPR, RB, VIC) and specialized literature. The distribution patterns were adapted from Giulietti \& Pirani (1988), Lima et al. (1997), Lima (2000) and Morim (2006): [1] Wide geographical distribution, which corresponds to the taxa that occur in Africa, Asia, Australasia, North America, Central America and South America; [2] South America, Central America and North America, taxa whose distribution is restricted to the Americas, from the United 


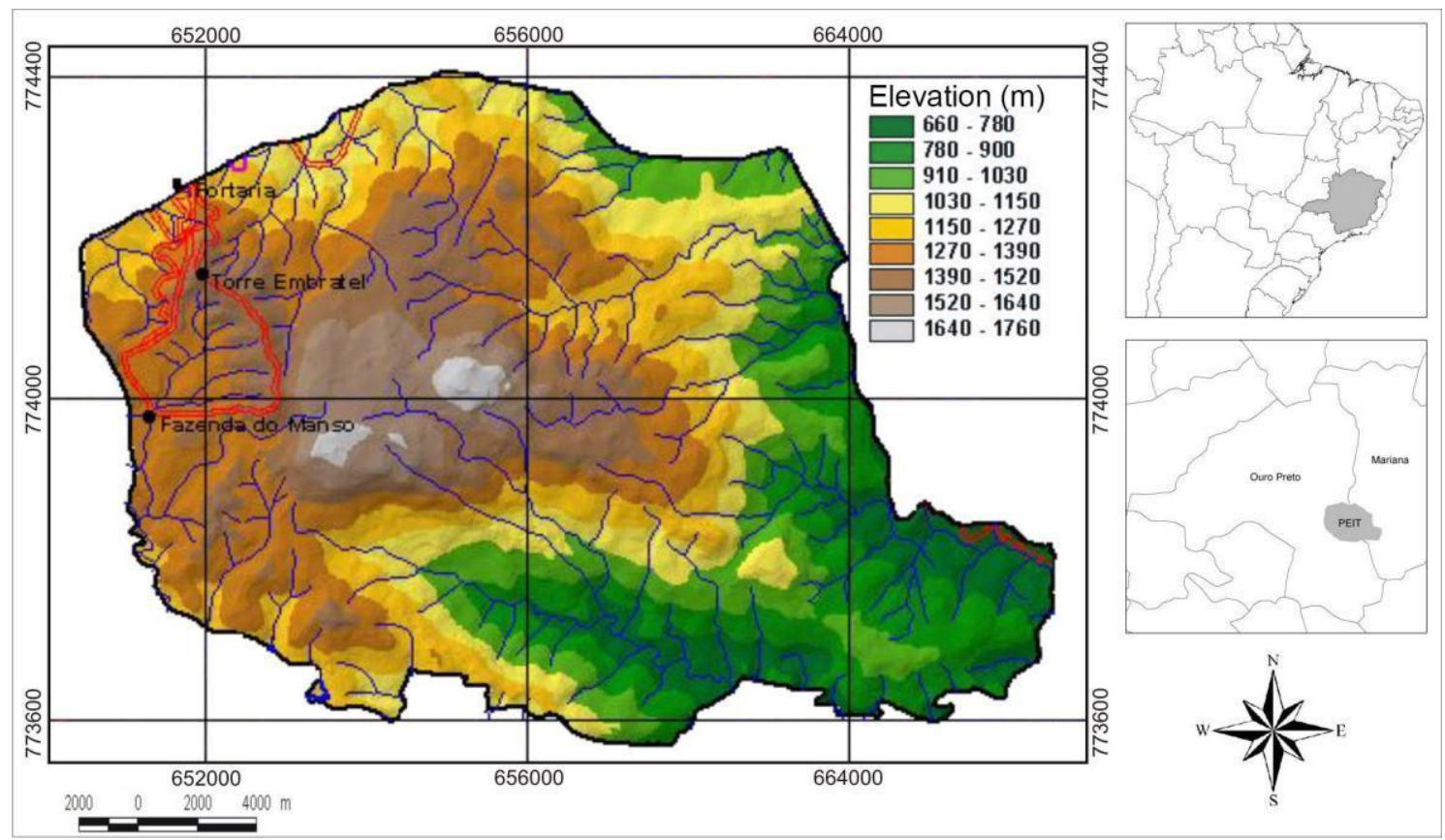

Figure 1. Location of the Itacolomi State Park.

Figura 1. Localização do Parque Estadual do Itacolomi.

States to southern Argentina; [3] Neotropical, taxa with a range of distribution in the tropics of South America, which can extend to Central America and Mexico; [4] West, Central and Eastern South America, taxa distributed across areas in the western, central and eastern South America, up to the far north of Venezuela, Suriname and Guyana; [5] Brazil-wide distribution, includes taxa widely distributed in all regions of Brazil; [6] Central-Eastern Brazil, taxa distributed in the midwest, northeast, southeast, and/or south of Brazil; [7] Atlantic-Northeast-Southeast-Southern Brazil, taxa that occur from the northeast to the south of Brazil; [8] Atlantic-Northeast-Southeastern Brazil, taxa with a range of distribution from northeast to southeastern Brazil; [9] Atlantic-Southeast- Southern Brazil, taxa distributed in the restricted range of the states of southeastern and southern Brazil; [10] Southeastern Brazil, taxa restricted to the states of Espírito Santo, Minas Gerais, Rio de Janeiro, and São Paulo; and [11] Espinhaço Range, taxa restricted to the highlands of the mountain range, in the states of Minas Gerais and Bahia.

The taxa were also classified as generalist or specialist species and according to habitat preference. The species exclusive to the Atlantic domain (which includes Rain Forest, Semideciduous and Deciduous Forests and Ombrophilous Mixed Forest) were considered specialist and those from other biomes, beyond the Atlantic area, such as the Amazon, Cerrado and/or Caatinga, were considered generalist. The classification of Veloso et al. (1991) modified by Oliveira-Filho (2009) was used for the determination of the taxon habitats. The term domain is used here according to Joly et al. (1999).

Maps of geographical taxa distribution representing each pattern were drawn based on information available in the literature and records from herbarium collections available at species (CRIA, 2013).

\section{Results}

The Leguminosae family in the Itacolomi State Park is represented by 102 specific and/or infraspecific taxa of 43 genera (Table 1). Papilionoideae was the subfamily with the largest number of taxa (48), followed by Mimosoideae (33) and Ceasalpinioideae (21). One of the species found, Trifolium repens, is exotic and occurs sub-spontaneously in the PEIT.

The most representative genera were Mimosa L. (11 spp.), Chamaecrista Moench. (9 spp.) and Inga Mill. (9 spp.), the former two ones predominated in Campos Rupestres and the latter in the Semideciduous Forests of PEIT.

Of the sampled taxa, 38 were exclusive to the Campos Rupestres (elevation range of 1000-1540m), including

Andira surinamensis (Bondt) Splitg. ex Pulle (Fig. 3a), Chamaecrista dentata (Vogel) H.S.Irwin \& Barneby (Fig. $\underline{3 b}$ ), C. hedysaroides (Vogel) H.S.Irwin \& Barneby (Fig. $\underline{3 b}), \quad$. ochnacea (Vogel) H.S.Irwin \& Barneby var. ochnacea (Fig. 3c), Mimosa montis-carasae Barneby (Fig. 3c) and M. ourobrancö̈nsis Burkart (Fig. 3d).

Forty nine taxa were exclusive to Semideciduous Forests, including Ormosia friburgensis Taub. ex Harms (Fig. 3d), Bionia bella Mart. ex Benth. (Fig. 4a) and Tachigali friburgensis (Harms) L.G. Silva \& H.C. Lima (Fig. 4a). Leguminosae were predominant in the submontane forests (elevation range of $620-700 \mathrm{~m}$ ) and less representative in lower highland and upper highland forests (elevation range of $700-1360 \mathrm{~m}$ ).

Fifteen taxa occurred in both vegetation types, such as Crotalaria breviflora DC. (Fig. 4b), Abarema langsdorfii (Benth.) Barneby \& J.W.Grimes (Fig. 4c) and Inga vulpina Mart. ex Benth. (Fig. 4d).

Most of the identified taxa were trees $(35 \%)$, followed by shrubs $(31.5 \%)$, herbs $(11.8 \%)$, lianas $(9.9 \%)$ and vines 

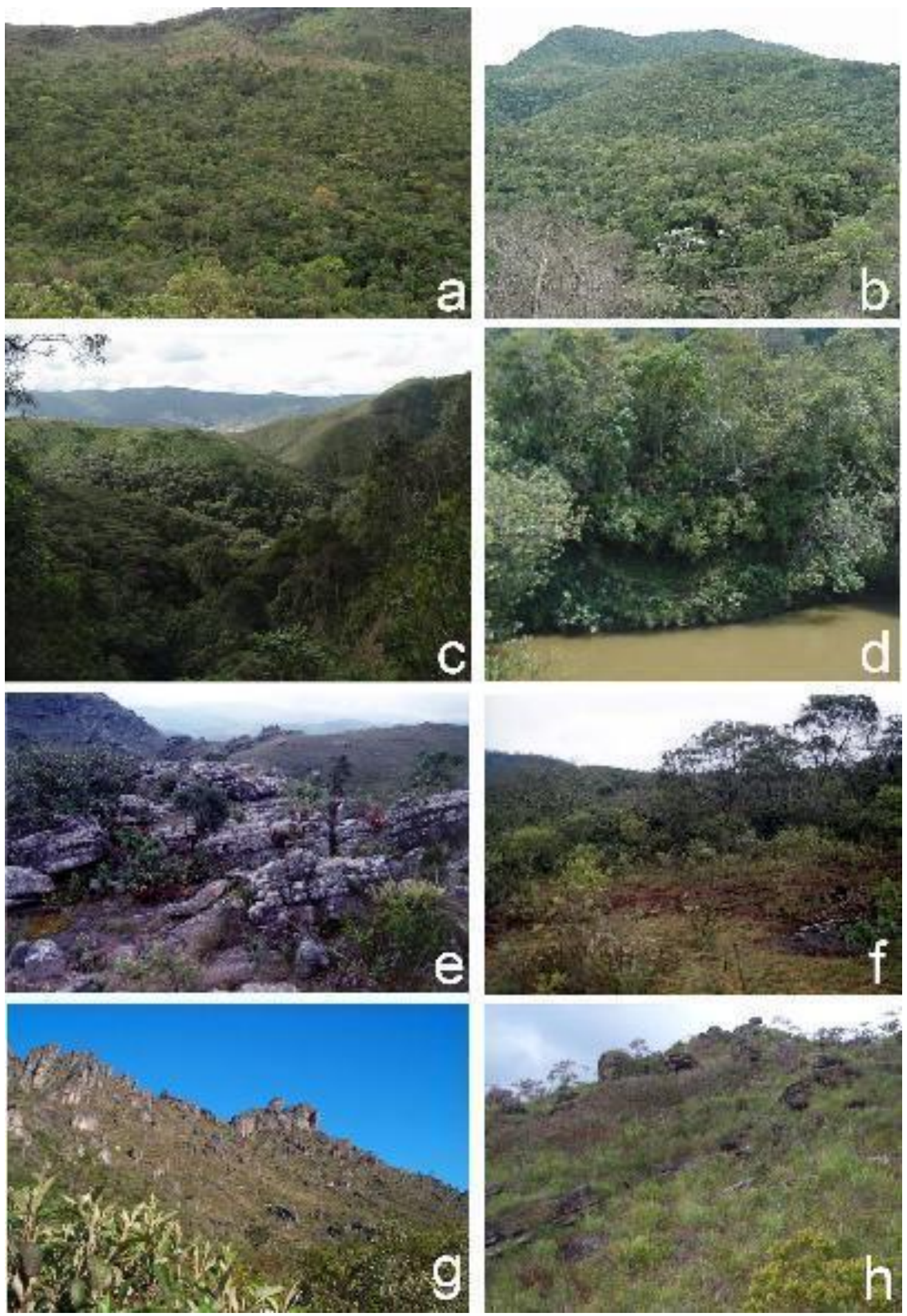

Figure 2. Semideciduous forest and campos rupestres of the Itacolomi State Park. a-d. semideciduous forest; e-h. campos rupestres.

Figura 2. Florestas Estacionais e campos rupestres do Parque Estadual do Itacolomi. a-d.

Florestas Estacionais; e-h. campos rupestres. 
$(9 \%)$. The subshrub habit was the least represented, with $2.8 \%$ of the taxa. Trees, vines and lianas were prevalent in the forest areas of the Park, while the shrubs, herbs and subshrubs were most common in the Campos Rupestres.

The analysis of the geographical distribution of 102 specific and infraspecific Leguminosae taxa of the PEIT covered the five geographical macroregions (Table 2): Wide geographic distribution (7.8\% of the taxa), South America, Central America and North America (4\%), Neotropical (16.5\%), West, Central and Easten South America (26.3\%), and distribution restricted to Brazil (45.6\% of the taxa).

Among the taxa of occurrence restricted to the Brazilian territory, seven geographic distribution patterns were defined (Table 2): Brazil-wide distribution (2.9\%), CentralEastern Brazil (11.6\%), Atlantic-Northeast-SoutheastSouthern Brazil 3.8\%), Atlantic-Northeast-Southeastern Brazil (6.8\%), Atlantic-Southeast- Southern Brazil (2.9\%), Southeastern Brazil (12.7\%) and endemic to the Espinhaço Range (4.9\%).

The correlation between the patterns of geographic distribution and the number of species per habitat in the PEIT (Fig. 5) showed that in the Semideciduous Forests there is predominance of species of the patterns West, Central and Eastern South America (18 spp), CentralEastern Brazil (9 spp) and Southeastern Brazil (9 spp.). Note also that 17 species are unique patterns of the Atlantic Forest domain. In Campos Rupestres there is predominance of species of the patterns Neotropical (09 spp), Wide geographic distribution (7 spp), South America, Central America and North America (4 spp) and Endemic to the Espinhaço Range (5 spp).

\section{Discussion}

The diversity of Leguminosae in PEIT can be considered high compared with other areas of the Espinhaço Range, losing in number of species only to the Serra do Cipó, where 104 species were listed according to Giulietti et al. (1987). Furthermore, it contains $15 \%$ of the Leguminosae diversity in the Campos Rupestres reported by Dutra et al. (2008a). Considering only the grassland vegetation, the PEI is the fifth richest area of Campo Rupestre in Leguminosae, while considering only the areas of the Iron Quadrangle, it is the first richest area in Leguminosae (Dutra et al . 2008a).

Besides this high diversity in Campos Rupestres of PEIT, the high percentage of taxons $(43 \%)$ in Submontane Forests corroborates the results found in the National Park of Itatiaia (PARNA Itatiaia), by Morim (2006). Elevational gradients in species diversity are nearly as ubiquitous as latitudinal gradients, and they provide a number of characteristics that make them perhaps more suitable for uncovering the underlying cause(s) of spatial variation in diversity, as the decline in species richness with increasing altitude is a common pattern in Tropical Forests (Colwell et al. 2004, Sanders \& Rabbeck 2012). This was recorded for Leguminosae in areas of Campos Rupestres by Dutra (2005), however, in these fields, as well as altitudinal variation, other factors such as topographic variation and heterogeneity of the substrate and microclimate are also determinants for the occurrence of species (Rapini et al. 2008)

Mimosa and Chamaecrista, the richest genera in number of species in the Campos Rupestres of the PEIT, are widely distributed in the Neotropics and characteristic of dry environments, such as the Cerrado (Schrire et al . 2005, Queiroz 2006). Inga, the most representative genus in the Semideciduous Forests of the PEIT, is prevalent in tropical and subtropical forests of Tropical America and has high diversity in the Atlantic Domain, with 22 species cited for secondary forests (León 1966, Garcia \& Fernandes 2013). The genera Lupinus and Calliandra, cited as diverse in the Campos Rupestres by Giulietti et al. (1997), were not found in the Campos Rupestres of the PEIT. The low representation or absence of species of these genera in other Campos Rupestres within the Iron Quadrangle had already been recorded by Dutra et al . (2008a).

The highest percentage of shrub and herbaceous species found in the Campos Rupestres is mainly due to the presence of representatives of Desmodium, Stylosanthes, Aeschynome and Zornia, among others, which are among the genera with high species richness in tropical grasslands. The richness of these genera in the extensive herbaceousshrub stratum prevalent in Campos Rupestres has been observed in other studies and is consistent with the percentage of habit variation in forest and grassland formations (Pirani et al. 2003, Zappi et al. 2003, Ferreira \& Forzza 2009).

The analysis of the geographical distribution of Leguminosae taxa in the PEIT showed a high percentage of taxa distribution restricted to the Brazilian territory, with predominance, under the phytogeographical aspect, of components of the flora of areas of Cerrado and Atlantic Forest. Morim (2006) reported that $65 \%$ of the species recorded in the Itatiaia National Park $(\mathrm{RJ})$ are restricted to Brazil. Filardi et al. (2007) and Nunes et al. (2007) found that $44 \%$ of the Leguminosae-Papilionoideae taxa growing in the National Park Serra da Canastra (MG) and 54\% of the Leguminosae-Mimosoideae taxa in the State Park of Rio Doce (MG) are unique to the flora of Brazil.

The species with the widest distribution patterns (Wide Geographic Distribution, South America, Central America and North America and Neotropical), are mostly herbaceous plants and subshrubs of Campos Rupestres and correspond to ruderal species that occur in different types of vegetation, mainly as weeds in degraded areas, being considered generalists (Miotto 1987, Fortuna-Perez 2010, Lima et al. 2010b) and well represented in the Campos Rupestres of the Iron Quadrangle (Dutra et al. 2008a). The wide distribution can also be explained by the presence of neotropical species that have the riverbanks as preferred habitat, such as Inga marginata and Inga vera subsp. affinis that occur in Submontane and Upper Highland Forests, respectively, corroborating Pennington (1997), who explained the occurrence of the wide distribution of these species in the Neotropics by the dispersal of fruits through hydrochory or zoochory.

In the distribution pattern Western, Central and Eastern South America, $56 \%$ of the species are restricted to semideciduous forests of the PEIT, among them, the specie

Anadenanthera colubrina var. colubrina is referred as representative in the Semideciduous Forests of Brazil. 
Table 1. Specific and infraspecific Leguminosae taxa of the Itacolomi State Park, their geographic distribution patterns, habits and vegetation types. $\mathrm{He}=$ herbaceous; $\mathrm{Li}=$ lianas; $\mathrm{Sb}=$ subshrubs; $\mathrm{Tr}=$ trees; $\mathrm{Sh}=$ shrubs; $\mathrm{Vi}=$ vines. $\mathrm{CRP}$

= campos rupestres $; \mathrm{SLF}=$ Semideciduous lower highland forest $; \mathrm{SMF}=$ semideciduous submontane forest; $\mathrm{SUF}=\mathrm{Semideciduous}$ upper highland forest.

Tabela 1 Táxons específicos e infra-específicos das Leguminosae do Parque Estadual do Itacolomi, seus padrões de distribuição geográfica, hábitos e formações vegetacionais. $\mathrm{He}=$ ervas; $\mathrm{Li}=$ lianas; $\mathrm{Sb}=$ subarbustos; $\mathrm{Sh}=$ arbustos; $\mathrm{Tr}$

= árvores; $\mathrm{Vi}=$ trepadeiras. $\mathrm{CPR}=$ campos rupestres; $\mathrm{SLF}=$ Floresta Estacional Montana; $\mathrm{SMF}=$ Floresta Estacional Submontana; $\mathrm{SUF}$

$=$ Floresta Estacional Altimontana.

\begin{tabular}{|c|c|c|c|}
\hline Distribution pattern & Specific and infraspecific taxa ${ }^{\boldsymbol{P}_{*}}$ & Habit & Vegetation type \\
\hline \multirow{7}{*}{ distribution } & Clitoria falcatat var. falcatat Lam."'"w" & $\mathrm{v}_{\mathrm{i}}$ & CRPISMF \\
\hline & $\begin{array}{l}\text { Desmodium adscendens (Sw.) DC. } \\
\text { Desmodium barbatum (L. } \mathrm{L} \text { (.) Beth. }\end{array}$ & $\mathrm{He}$ & CRP/SUF/SLF/ SMF \\
\hline & $\begin{array}{l}\text { Desmodum barbatum (L.) Benth. } \\
\text { Desmodium incanum DC. }<0\end{array}$ & $\mathrm{He}$ & $\begin{array}{l}\text { CRP } \\
\text { CRP }\end{array}$ \\
\hline & Desmoadium incanum DC. & $\begin{array}{l}\mathrm{He} \\
\mathrm{Sb}\end{array}$ & CRP/SUF/SLF \\
\hline & Mimosa pudica var. hispida Brenan $^{4}$ & $\mathrm{Sb}$ & CRP \\
\hline & Zornia reticulata $\mathrm{Sm}^{11}$ & $\mathrm{He}$ & CRP \\
\hline & Trifolium repens $\mathrm{L}^{\circ}{ }^{\circ}<\mathrm{u}$ & $\mathrm{He}$ & SUF \\
\hline South America, Central & Centrosema virginianum $\left(\right.$ L.) Benth. ${ }^{J,+J}$ & Vi & $\mathrm{CRP}$ \\
\hline $\begin{array}{l}\text { America and North } \\
\text { America }\end{array}$ & $\begin{array}{l}\text { Chamaecrista rotundifolia var. rotundifolia } \text { (Pers.) Greene } \\
\text { Indigofera suffruticosa Mill. } \\
\text { Stylosanthes viscosa }(\text { L.) Sw. }\end{array}$ & $\begin{array}{l}\mathrm{He} \\
\mathrm{Ab} \\
\mathrm{He}\end{array}$ & $\begin{array}{l}\text { CRP } \\
\text { CRP/SMF } \\
\text { CRP }\end{array}$ \\
\hline \multirow[t]{16}{*}{ Neotropical } & Aeschynomene elegans var. elegans Schltdl. \& Cham. ${ }^{2 u}$ & $\mathrm{He}$ & CRP/SUF \\
\hline & Anadenanthera peregrina L. (Speg.) ${ }^{1,1 \mathrm{v}, \angle \mathrm{U}}$ & $\operatorname{Tr}$ & SUF \\
\hline & Andira surinamensis (Bondt) Splitg. ex Pulle ${ }^{J,+,}$ & $\mathrm{Ab}$ & CRP \\
\hline & Calopogonium mисипoides Desv. ${ }^{\mathrm{TJ}}$ & $\mathrm{Vi}$ & CRP \\
\hline & Crotalaria micans Link ${ }^{24}$ & $\mathrm{Ab}$ & CRP \\
\hline & Desmodium affine Schltdl. ${ }^{<, ~} \mathrm{v}$ & $\mathrm{He}$ & CRP \\
\hline & Inga marginata Willd. ${ }^{24,+0}$ & $\operatorname{Tr}$ & SMF \\
\hline & Inga vera subsp. affinis (DC.) T.D.Penn ${ }^{<4,4 u}$ & $\operatorname{Tr}$ & SUF/SMF \\
\hline & Machaerium hirtum (Vell.) Stellfeld ${ }^{\mathcal{}}, 4 \mathrm{v}, \mathrm{\nu}$ & $\operatorname{Tr}$ & SMF \\
\hline & Mimosa diplotricha var. diplotricha C.Wright ex Sauvalle ${ }^{4}$ & $\mathrm{Ab}$ & CRP \\
\hline & Platypodium elegans Vogel ${ }^{4,, 01,00}$ & $\operatorname{Tr}$ & SMF \\
\hline & Poiretia punctata (Willd.) Desv. ${ }^{43}$ & $\mathrm{Li}$ & SMF \\
\hline & Pterocarpus rohrii Vahl ${ }^{2 y, 34}$ & $\operatorname{Tr}$ & SMF \\
\hline & Rhynchosia reticulata (Sw.) DC. ${ }^{40}$ & Vi & CRP \\
\hline & Stylosanthes guianensis (Aubl.) Sw. ${ }^{1<,<0}$ & $\mathrm{He}$ & CRP \\
\hline & Vigna peduncularis (Kunth) Fawc. \& Rendle ${ }^{\text {o }}$ & Vi & $\mathrm{CRP} / \mathrm{SUF}$ \\
\hline \multirow{26}{*}{$\begin{array}{l}\text { Western - Central- } \\
\text { Eastern South America }\end{array}$} & Anadenanthera colubrina (Vell.) Brenan var. colubrina ${ }^{1, \angle 0}$ & $\operatorname{Tr}$ & SMF \\
\hline & $\begin{array}{l}\text { Bauhinia longifolia (Bong.) Steud. } \\
\text { Bauhinia ungulata var. cuiabensis (Bong.) Vaz }\end{array}$ & $\mathrm{Tr}$ & $\begin{array}{c}\text { SMF } \\
\text { CRP/SLF/SMF }\end{array}$ \\
\hline & Bowdichia virgilioides Kunth ${ }^{<0}$ & $\operatorname{Tr}$ & SMF \\
\hline & Calliandra parvifolia (Hook. \& Arn.) Speg. ${ }^{J}$ & $\mathrm{Tr}, \mathrm{Ab}$ & SMF \\
\hline & Chaetocalyx longiflora Benth. ex A.Gray Ju & $\mathrm{Vi}$ & SMF \\
\hline & Chamaecrista langsdorfii (Kunth ex Vogel) Britton ex Pittier ${ }^{20}$ & $\mathrm{Ab}$ & CRP \\
\hline & Chamaecrista trichopoda (Benth.) Britton \& Rose ex Britton \& Killip ${ }^{<0}$ & $\mathrm{He}$ & CRP \\
\hline & Camptosema scarlatinum var. pohlianum (Mart. ex Benth.) Burkart ${ }^{20}$ & $\mathrm{Vi}$ & CRP \\
\hline & Copaifera reticulata Ducke ${ }^{1 t^{t}}$ & $\operatorname{Tr}$ & SUF/SLF/SMF \\
\hline & Crotalaria paulina Schrank ${ }^{<}$ & $\mathrm{Sb}$ & SMF \\
\hline & Dalbergia frutescens var. frutescens (Vell.) Britton ${ }^{14}$ & $\mathrm{Ab} / \mathrm{Li}$ & $\mathrm{CRP} / \mathrm{SUF}$ \\
\hline & Dalbergia revoluta Ducke $^{14}$ & $\operatorname{Tr}$ & SMF \\
\hline & Desmodium subsericeum Malme ${ }^{<, ~} \mathrm{v}$ & $\mathrm{He}$ & CRP \\
\hline & Dioclea violacea Mart. ex Benth. ${ }^{10}$ & $\mathrm{Li}$ & SMF \\
\hline & Inga cylindrica (Vell.) Mart. ${ }^{24,40}$ & $\operatorname{Tr}$ & SUF/SLF/SMF \\
\hline & Inga edulis Mart. ${ }^{<,+}+\mathrm{u}$ & $\operatorname{Tr}$ & SMF \\
\hline & Inga ingoides (Rich.) Willd. ${ }^{<4,40}$ & $\operatorname{Tr}$ & SLF/SMF \\
\hline & Machaerium aculeatum $\operatorname{Raddi}^{\text {} v}$ & $\mathrm{Li}$ & CRP/SLF/SMF \\
\hline & Machaerium brasiliense Vogel $^{4 \mathrm{v}, \mathrm{J}}$ & $\operatorname{Tr} / \mathrm{Ab}$ & CRP/SLF/SMF \\
\hline & Machaerium nyctitans (Vell.) Benth. ${ }^{4 /}$ & $\operatorname{Tr}$ & SUF/SLF \\
\hline & Machaerium villosum Vogel ${ }^{凶 U}$ & $\operatorname{Tr}$ & SUF/SLF/SMF \\
\hline & Mimosa pigra var. dehiscens (Barneby) Glazier \& Mackinder $^{4}$ & $\mathrm{Ab}$ & CRP \\
\hline & Periandra mediterranea (Vell.) Taub. & $\mathrm{Ab}$ & CRP \\
\hline & Piptadenia adiantoides (Spreng.) J.F.Macbr. ${ }^{\iota 0}$ & $\mathrm{Li}$ & SUF/SMF \\
\hline & Senna pendula var. glabrata (Humb. \& Bonpl. ex Willd.) H.S.Irwin \& Barneby ${ }^{<0}$ & $\mathrm{Ab}$ & $\mathrm{CRP} / \mathrm{SUF}$ \\
\hline & Sesbania virgata (Cav.) Pers. ${ }^{20}$ & $\mathrm{Ab}$ & CRP \\
\hline \multirow[t]{3}{*}{ Brazil-wide distribution } & Crotalaria breviflora DC. ${ }^{<0}$ & $\mathrm{He} / \mathrm{Ab}$ & CRP/SUF \\
\hline & Inga sessilis (Vell.) Mart. ${ }^{\iota J}$ & $\operatorname{Tr}$ & SUF \\
\hline & Phanera radiata (Vell.) Vaz ${ }^{\text {Jo }}$ & $\mathrm{Li}$ & SLF \\
\hline \multirow[t]{9}{*}{ Central-Eastern Brazil } & Andira fraxinifolia Benth. ${ }^{4 \prime}$ & $\operatorname{Tr}$ & SLF/SMF \\
\hline & Cassia ferruginea (Schrad.) Schrad. ex DC. var. ferruginea ${ }^{\circ 0}$ & $\operatorname{Tr}$ & SMF \\
\hline & Centrosema coriaceum Benth. & $\mathrm{Vi}$ & CRP \\
\hline & Crotalaria velutina Benth. ${ }^{¿<}$ & $\mathrm{He}$ & CRP \\
\hline & Dalbergia villosa (Benth.) Benth. var. villosa ${ }^{\supset 4}$ & $\mathrm{Ab} / \mathrm{Tr}$ & CRP/SUF/SLF/SMF \\
\hline & Machaerium oblongifolium Vogel $^{21}$ & $\mathrm{Li}$ & SUF/SMF \\
\hline & Mimosa bimucronata (DC.) Kuntze var. bimucronata $^{4,10}$ & $\mathrm{Ab}$ & SLF/SMF \\
\hline & Mimosa dolens Vell. var. dolens ${ }^{4,10}$ & $\mathrm{Ab}$ & CRP \\
\hline & Piptadenia gonoachantha (Mart.) J.F.Macbr. $34,41,56$ & $\operatorname{Tr}$ & SUF/SMF \\
\hline
\end{tabular}




\section{Atlantic - Northeast- Southeast-Southern Brazil}

Atlantic - NortheastSoutheastern Brazil

Atlantic - SoutheastSouthern Brazil

Southeastern Brazil
Endemic to the Espinhaço Range

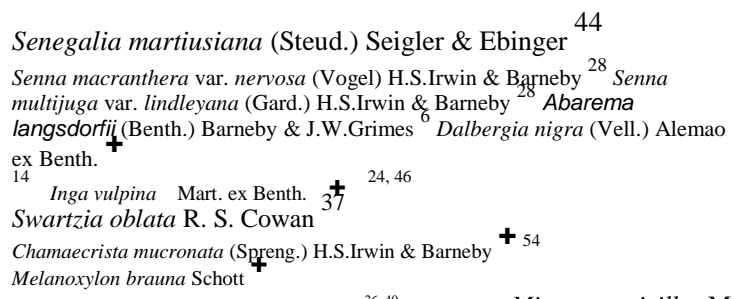

\footnotetext{
+ Species threatened by extinction according to Biodiversitas (2005) and Brasil (2008).

* References of the geographic distributions: ${ }^{1}$ Altshul (1964), ${ }^{2}$ Azevedo (1981), ${ }^{3}$ Barbosa -Fevereiro (1977), ${ }^{4}$ Barneby (1991), ${ }^{5}$ Barneby (1998), ${ }^{6}$ Barneby

\& Grimes (1996), ${ }^{7}$ Barroso (1965), ${ }^{8}$ Bentham (1859), ${ }^{9}$ Benham (1876), ${ }^{10}$ Brandão (1992), ${ }^{11}$ Brandão (1996), ${ }^{12}$ Brandão \& Costa (1979) ${ }^{16}{ }^{13}$ Burkart (1970), ${ }_{14}^{14}$ Carvalho (1997), ${ }^{15}$ Carvalho-Okano \& Leitão-Filho (1985), ${ }^{16}$ Dutra \& Morim (2011), ${ }^{17}$ Dwyer (1951), ${ }^{18}$ Eisinger (1987), ${ }^{19}$ Fantz (1980) ${ }^{20}{ }^{2}$ Fernandes (1996), ${ }^{21}$ Filardi (2011), ${ }^{22}$ Flores (2004), ${ }^{23}$ Flores (2011), ${ }^{24}$ Garcia (1998), ${ }^{25}$ Garcia \& Fernandes (2013), ${ }^{26}$ ILDIS (2011) ${ }^{2 \%}$ Irwin \& Barneby $(1978),{ }^{28}$ Irwin

\& Barneby (1982), ${ }^{29}$ Lewis (1987), ${ }^{30}$ Lewis \& Lima (1991) ${ }^{31}$ Lima (2000), ${ }^{32}$ Lima (2011a), ${ }^{33}$ Lima (2011b), ${ }^{34}$ Lima et al. (1994), ${ }_{32}$ Lima et al. (2010c), ${ }^{36}$ Lorenzi

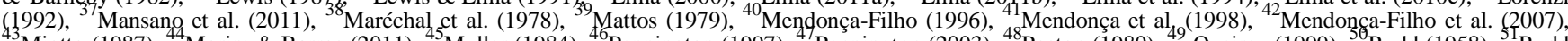
${ }^{43}$ Miotto (1987), ${ }^{44}$ Morim \& Barros (2011), ${ }^{45}$ Mullęr (1984), ${ }^{46}$ Pennington (1997) ${ }_{55}{ }_{5}$ Pennington (2003), ${ }^{48}$ Poston $(1980),{ }_{59}$ Queiroz (1999), ${ }^{59}$ Rudd (1958), ${ }^{51}$ Rudd (1965), ${ }^{52}$ Sartori \& Tozzi (1998), ${ }^{53}$ Scalon (2007), ${ }^{54}$ Souza \& Bortoluzzi (2011a), ${ }^{55}$ Souza \& Bortoluzzi (2011b), ${ }^{56}$ Tamashiro (1989),

${ }^{57}$ Vaz \& Tozzi (2003), ${ }^{58}$ Vaz (2011).
}

It is also considered as a specialist species of the Atlantic domain by Lima (2000). However, this taxon is found in areas of Caatinga in northeastern Brazil and in part of Minas Gerais and Maranhão, in Seasonal Forests in the states of Mato Grosso do Sul and Parana, as well as in northeastern Argentina and southeastern Bolivia (Prado \& Gibbs 1993); these vegetation types are currently recognized as Seasonally Dry Tropical Forests (SDTF), according to Pennington et al. $(2000,2004,2006)$ and Miles et al. (2006).

In the pattern Central-Eastern Brazil there is also predominance of species of Semideciduous Forests of the PEIT, such as Andira fraxinifolia and Piptadenia gonoacantha, which are generalist species, corroborating Oliveira- Filho \& Ratter (1995) that describe this area as an important migratory corridor, through the gallery forests of the Cerrado and Atlantic Forest. Although PEIT lies in a transition zone between the Atlantic Forest and areas of Cerrado, its legume species indicate that the Atlantic Forest domain has a greater number of taxa than the Cerrado.
In the pattern Southeastern Brazil, of the 13 taxa identified, nine were exclusive to the Semideciduous Forests. Abarema obovata and Bionia bella occur in upper highlands, lower highlands and submontane forests of the PEIT and are restricted to the Atlantic Forest domain, growing in submontane or seasonal forests and highland areas related mainly to the Mantiqueira Range, respectively (Barneby \& Grimes 1996, Queiroz 1999, 2008). Inga schinifolia, Ormosia friburgensis and Senna pneumatica are specialist species and occur only in the upper highland forests of the PEIT, confirming reports by Rudd (1965), Garcia (1998) and Irwin \& Barneby (1982).

Among the endemic species of the Espinhaço Range, all were exclusive to the Campos Rupestres, some can be considered microendemic because they occur only in two or three localities. Chamaecrista dentata is restricted to the Cipó Range and Itacolomi Range (Irwin \& Barneby 1978); C. hedysaroides occurs in the region of Diamantina, Ouro Preto and Caraça Range (Irwin \& Barneby 1978); 

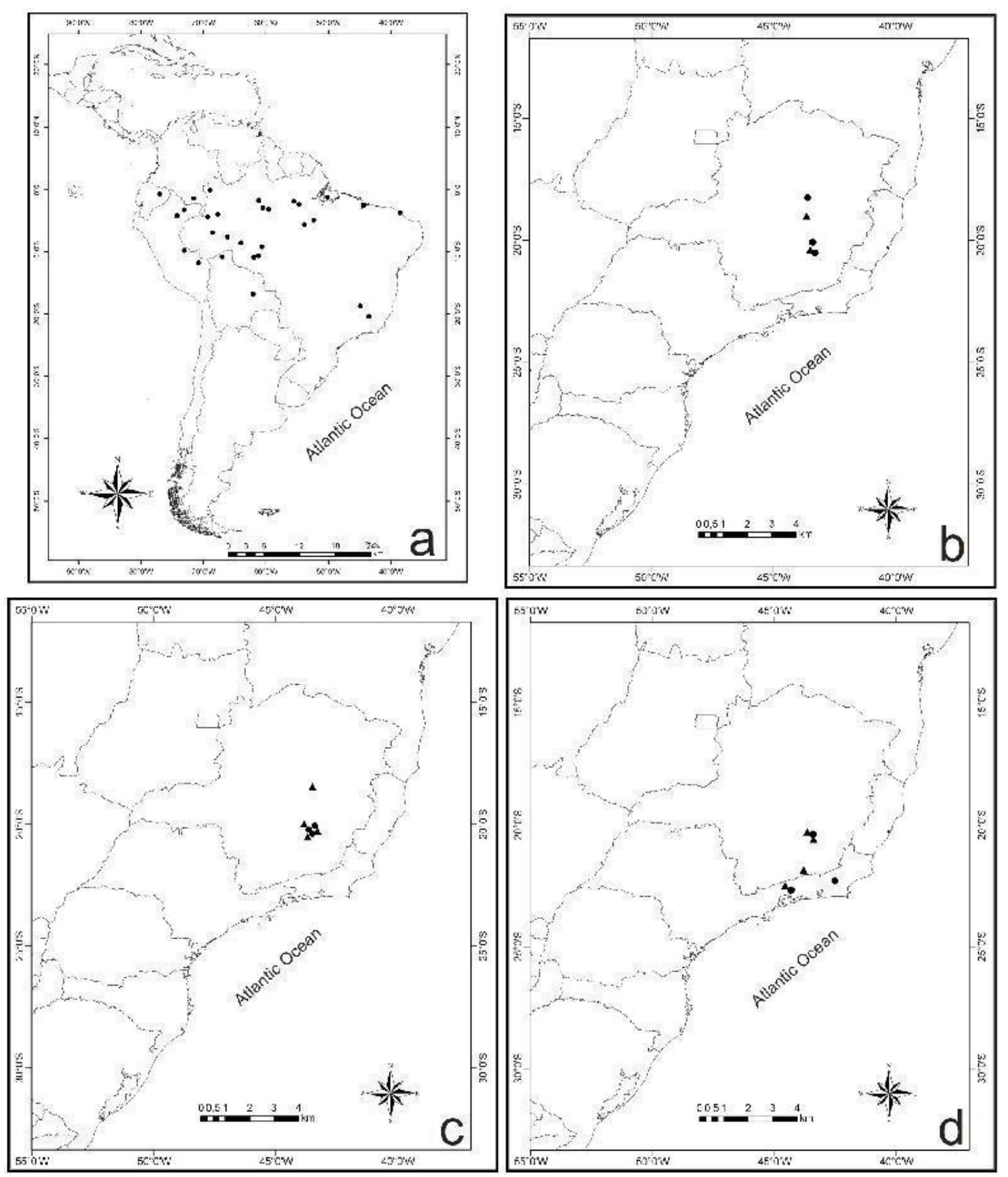

Figure 3. Distribution patterns a. Neotropical Andira surinamensis (Source: Pennington 2003, Mattos 1979); b. Endemic to the Espinhaço Range Chamaecrista dentata $(\boldsymbol{\Delta})$ and Chamaecrista hedysaroides ( $)$ (Source: Irwin \& Barneby 1982); c. Chamaecrista ochnacea var. ochnacea $(\boldsymbol{\Delta})$ and Mimosa montis-carasae ( ) (Sources: Irwin \& Barneby 1982, Dutra 2009); d. Southeastern Brazil Mimosa ourobrancoënsis

(A ) and Ormosia friburgensis ( ) (Sources: Dutra 2009, Rudd 1965).

Figura 3. Padrões de distribuição a. Neotropical Andira surinamensis (Fontes: Pennington 2003, Mattos 1979); b.

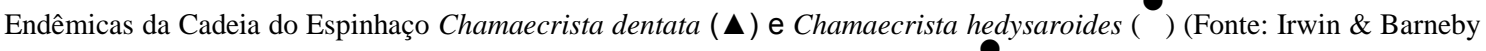
1982); c. Chamaecrista ochnacea var. ochnacea ( $\mathbf{\Delta}$ ) e Mimosa montis-carasae ( ) (Fontes: Irwin \& Barneby 1982, Dutra 2009); d. Brasil Sudeste Mimosa ourobrancoënsis

( ( ) e Ormosia friburgensis ( ) (Fontes: Dutra 2009, Rudd 1965). 
C. ochnacea var. ochnacea grows in Nova Lima, Ouro Branco Range and Itacolomi Range (Irwin \& Barneby 1978, Dutra et al. 2008b); C. rotundata var. grandistipula is limited to the region of Diamantina, Cipó Range and Itacolomi Range (Rando \& Pirani 2011); and Mimosa montis-carasae, unique to Caraça Range and Itacolomi Range (Barneby 1991, Dutra et al. 2008c).

In the PEIT, $45 \%$ of the listed Chamaecrista species are endemic to the Espinhaço Range, confirming the high degree of endemism of the genus for the flora of this mountain system, showing a pattern already identified for mainly the families of Eriocaulaceae, Velloziaceae, Xyridaceae, and Lythraceae (Giulietti et al. 1987). The states of Bahia and Minas Gerais are cited as a center of diversity for Chamecrista, mainly the Cerrado and Campos Rupestres, especially the portion of the Espinhaço
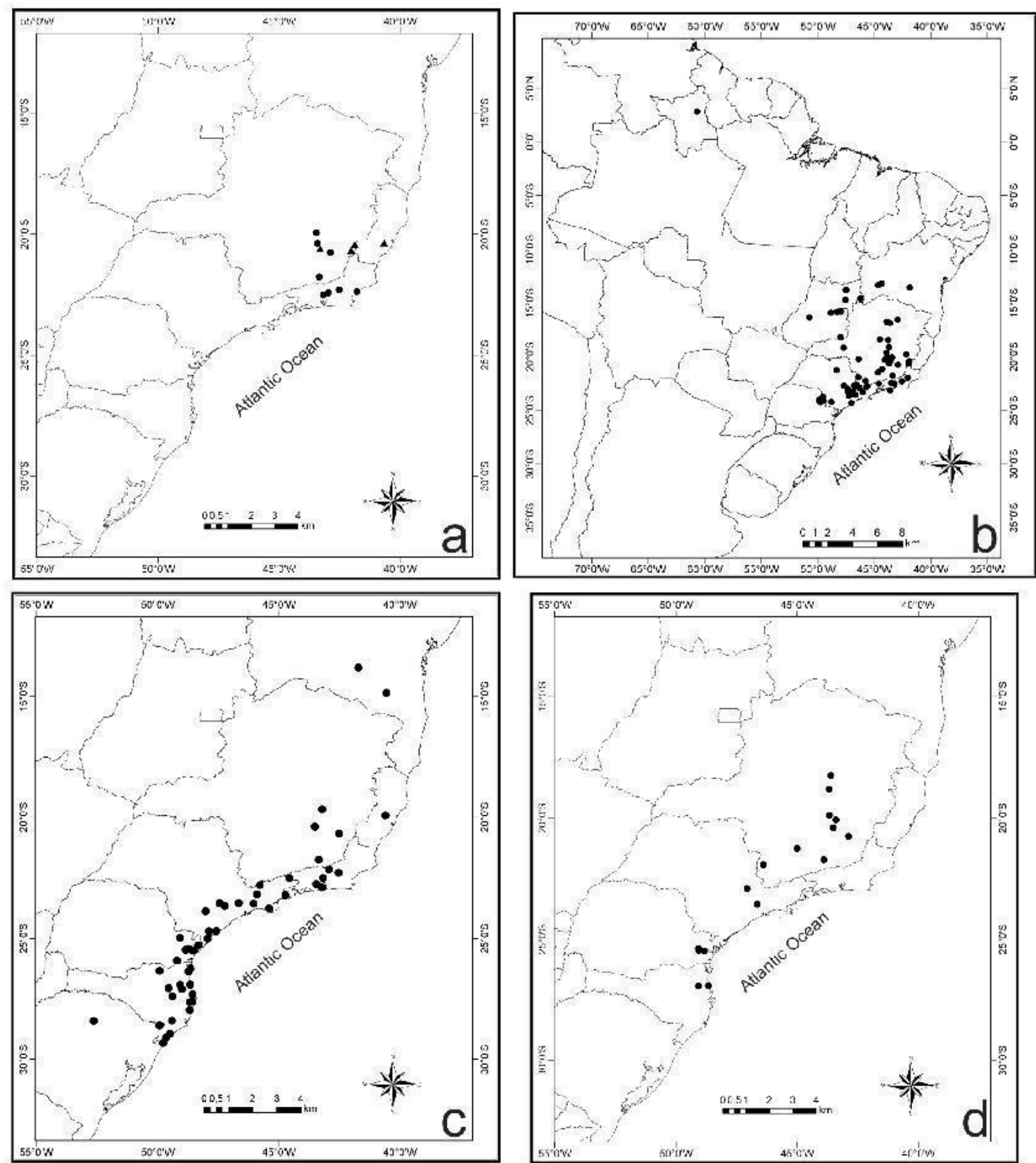

Figure 4. Distribution patterns a. Southeastern Brazil Bionia bella $(\boldsymbol{\Delta})$ and Tachigali friburgensis $(\boldsymbol{)})$ (Sources: Queiroz 1999, 2008, Silva 2007); b. Brazil-wide distribution Crotalaria breviflora (Source: Flores 2004, 2011); c. Atlantic-Northeast-Southeast-Southern Brazil Abarema langsdorfii (Source: Barneby \& Grimes 1996); d. Atlantic-Northeast-Southeast-Southern Brazil Inga vulpina (Source: Garcia 1998).

Figura 4. Padrões de distribuição a. Brasil Sudeste Bionia bella $(\boldsymbol{\Delta})$ e Tachigali friburgensis ( ) (Fontes: Queiroz 1999, 2008, Silva 2007); b. Brasil ampla distribuição Crotalaria breviflora (Fontes: Flores 2004, 2011); c. Brazil Atlântico-Nordeste-Sudeste-Sul Abarema langsdorfii (Fonte: Barneby \& Grimes 1996); d. Brazil Atlântico-Nordeste-Sudeste-Sul Brazil Inga vulpina (Fonte: Garcia 1998). 
Table 2. Number of specific and infraspecific Leguminosae taxa in the Itacolomi State Park and percentage of geographic distribution patterns.

Tabela 2. Número de táxons específicos e infra-específicos de Leguminosae do Parque Estadual do Itacolomi e porcentagem dos padrões de distribuição geográfica.

\begin{tabular}{lcc}
\hline \multicolumn{1}{c}{ Distribution pattern } & Nr. of taxa & \% of taxa \\
\hline Wide geographic distribution & 8 & 7.8 \\
South America, Central America and North America & 4 & 4.0 \\
Neotropical & 16 & 15.7 \\
West, Central and Eastern South America & 27 & 26.5 \\
Restricted to Brazil & 47 & 46.0 \\
Brazil-wide distribution & 3 & 2.9 \\
Central-Eastern Brazil & 12 & 11.6 \\
Atlantic-Northeast-Southeast-Southern Brazil & 4 & 3.8 \\
Atlantic-Northeast-Southeastern Brazil & 7 & 6.8 \\
Atlantic-Southeast-Southern Brazil & 3 & 2.9 \\
Southeastern Brazil & 13 & 12.7 \\
Endemic to the Espinhaço Range & 5 & 4.9 \\
\hline
\end{tabular}

Range in Minas Gerais, which has several endemic species (Irwin \& Barneby 1982, Lewis 1987, Giulietti \& Pirani 1988, Harley 1988, Dutra et al. 2008a, Rando \& Pirani 2011). In this region, some series of the genus had a significant diversification, which may have been caused by periods of climatic fluctuations that occurred in the Quaternary and resulted in the irregularity in the gene flow between populations and in the evolution of new species (Giulietti et al . 1997).

The distribution patterns of Leguminosae taxa in the Park show that its flora consists of floristic elements of both the Atlantic Forest and the Cerrado, the two Brazilian biomes considered hotspots (Mittermeier et al. 2005). The Semideciduous Forests of the PEIT receive the combined contribution of elements from different forest types, especially from those of the Atlantic Forest domain, since the distribution patterns of about $25 \%$ of the species were restricted to the Atlantic Forest. The Campos Rupestres, however, besides the high number of endemic taxa of the Espinhaço Range, receive the contribution of elements from the Cerrado and the Atlantic Forest, due to the presence of Semideciduous Forests that occur in the lower parts of the PEIT, corroborating Santos et al. (2011) that point out the geographical proximity as one of the factors influencing the

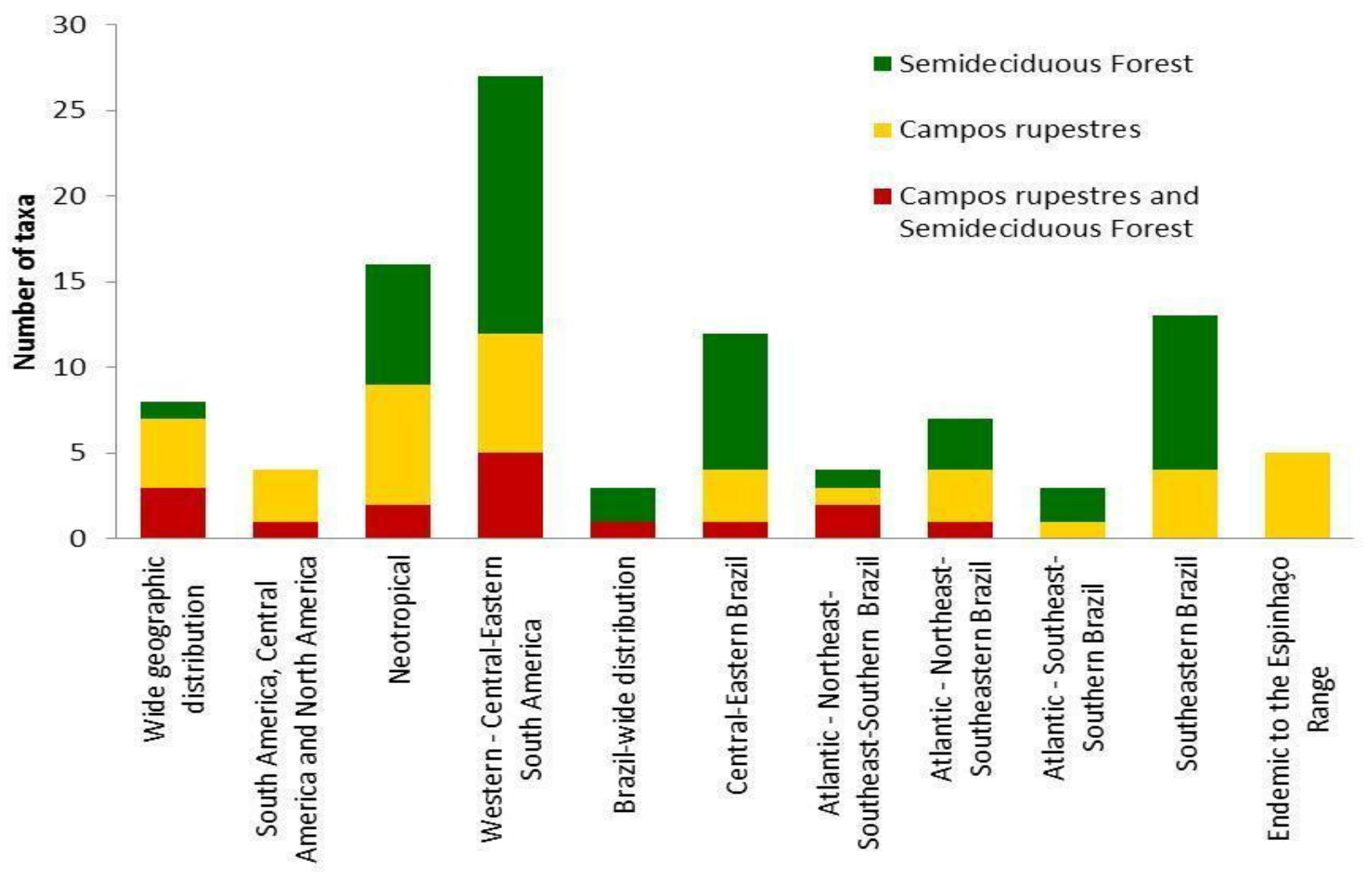

Figure 5. Correlation between geographic distribution patterns and number of taxa found in vegetation types of the Itacolomi State Park.

Figura 5. Correlação entre os padrões de distribuição geográfica e o número de espécies encontradas nas fitofisionomias do Parque Estadual do Itacolomi. 
phytogeographic patterns in the Quadrilátero Ferrifero and also, as proposed by Harley (1995), the sectorization of the Espinhaço Range. Harley (1995) referred the Campos Rupestres that are restricted to the higher and isolated areas and have more humid climate, with greater contact with the Semideciduous Forests than the Cerrado, to the southern sector of the Range, which comprises the south of Belo Horizonte and the Ouro Preto region.

Despite the presence of species endemic to the Espinhaço, the analysis of distribution patterns of the Leguminosae in the PEIT does not support the distribution patterns typically found in other areas of the Espinhaço Range, in which forest species are predominantly of wide distribution and the herbaceous-shrub species exhibit stricter standards (Giulietti \& Pirani 1988) caused by the history of the region, such as migration routes and past climate changes occurred in southeastern Brazil during the Pleistocene, which promoted the isolation of species (Giulietti et al . 1997).

Among the species found in the Park, 15 are of interest for the conservation of PEIT, because five are endemic to the Espinhaço mountain range and ten appear in the lists of endangered species of the flora of Brazil and Minas Gerais (Table 2). In areas of Campos Rupestres within the Park, the species Chamaecrista dentata, with only two populations, and Mimosa ourobrancoënsis, with a single population, are noteworthy. In these forest formations, many species have a very restricted distribution or are rare.

Senna pneumatica and Ormosia friburgensis are restricted to the Upper Highland Forests, and Melanoxylon brauna occurs in Submontane Forests. So far, only one population of each of these species has been found. Dalbergia nigra occurs in Lower Highlands and Submontane Forests with two populations identified. Bionia bella grows in Lower Highlands, Submontane and Upper Highland Forests, with scarce populations scattered throughout the forest formations. It is worth mentioning that the occurrence of all these taxa is restricted to the Atlantic Forest domain.

The representatives of the genera Abarema, Bionia, Chamaecrista, Inga, and Mimosa have ornamental potential, whereas Dalbergia nigra and Melanoxylon brauna have timber potential. Therefore, these results do not only reinforce the important role of the PEIT in the conservation of the flora in the southern Espinhaço Range, but also highlight the existence of stocks of species threatened by extinction or with potential for sustainable use.

The presence of distinct and heterogeneous floras in vegetational gradients makes the PEIT an area with high biological diversity. Messias \& Souza (2006) reported 80 species of Leguminosae for the PEIT. This study shows an increase of $27.5 \%$ in the number of species within the park, which demonstrates the importance of research involving knowledge of biodiversity at the local scale.

Despite being a fully protected conservation unit, difficulties of managing the park prevents effective species protection and the vegetation of the PEIT is still subject to different impacts by uncontrolled urban sprawl, frequent fires, invasion of exotic species and firewood extraction (Messias \& Souza 2006). Within the park, it deserves attention, in the areas of Campo Rupestre, the trails Calais and the water catchment in Serrinha, home to endemic species of the Espinhaço, and in the Semideciduous Forests, the upper highlands forests, home to most of the forest species of the PEIT that are threatened with extinction.

The findings of this study on the Leguminosae family demonstrate the importance of conserving the vegetation of the Itacolomi Range and the need for studies on other plant families, with a view to the implementation of effective protection policies for the forests and fields of the PEIT.

\section{Acknowledgements}

We thank to $\mathrm{CNPq}$ (Conselho Nacional de Desenvolvimento Científico e Tecnológico), for the master's scholarship granted to the second author; to IEFMG (Instituto Estadual de Florestas de Minas Gerais ) for the logistics in the Itacolomi State Park; to Mário E.F. Araújo, for the assistance at the field work; to Evelyn Jardim de Oliveira for the English review; to anonymous reviewer for critically reading the manuscript.

\section{References}

ALTSHUL, S. von R. 1964. A taxonomic study of the genus Anadenanthera. Contr. Gray Herb. 193:1-65.

AZEVEDO, A.M.G. 1981. O gênero Desmodium Desv. no Brasil-considerações taxonômicas. Dissertação de Mestrado, Universidade Estadual de Campinas, Campinas, $315 \mathrm{p}$.

BARBOSA-FEVEREIRO, V.P. 1977. Centrosema (A.P. de Candolle) Benthan do Brasil - Leguminosae-Faboideae. Rodriguésia 42:159-219.

BARNEBY, R.C. 1998. Silk tree, Guanacaste, Monkey's earring: a generic system for the synandrous Mimosaceae of the Americas. Mem. New York Bot. Gard. 74:1-223.

BARNEBY, R.C. 1991. Sensitivae Censitae. A description of the genus Mimosa Linnaeus (Mimosaceae). New World. Mem. New York Bot. Gard. 65:1-835.

BARNEBY, R.C. \& GRIMES, J. 1996. Silk tree, Guanacaste, Monkey's earring: a generic system for the synandrous Mimosaceae of the Americas. Mem. New York Bot. Gard. 74:1-292.

BARROSO, G.M. 1965. Leguminosas da Guanabara. Arquivos do Jardim Botânico do Rio de Janeiro 18:109-177.

BARROSO, G.M., PEIXOTO, A.L., COSTA, C.G., ICHASSO, C.L.F., GUIMARÃES, E.F. \& LIMA, H.C. 1991. Sistemática das Angiospermas do Brasil, vol. 2. Imprensa Universitária, Viçosa.

BENTHAM, G. 1859. Papilionaceae. In: Flora Brasiliensis. (C.F.P. Martius, S. Endlicher \& I. Urban, eds.). F. Fleischer, Lipsiae, v. 15, p. 1-215.

BENTHAM, G. 1876. Mimoseae. In: Flora Brasiliensis. (C.F.P. Martius, S. Endlicher \& I. Urban, eds.). F. Fleischer, Lipsiae, v. 15, p. 34-499.

BIODIVERSITAS. 2005. Lista da flora brasileira ameaçada de extinção segundo avaliação no workshop. http://www. biodiversitas.org.br/florabr/lista_florabr.pdf. (accessed em 14/02/2011)

BRANDÃO, M. 1992. Gênero Aeschynomene L.: espécies mineiras e sua distribuição no país. Daphne 2:27-46. 
BRANDÃO, M. 1996. O gênero Zornia Gmell. no Estado de Minas Gerais. Daphne 6:21-39.

BRANDÃO, M. \& COSTA, N.M.S. 1979. O gênero Stylosanthes Sw. no Brasil. EPAMIG, Belo Horizonte.

BRANDÃO, M. \& GAVILANES, M.L. 1994. Composição Florística das áreas recobertas pela Caatinga na área mineira da SUDENE. Informe Agropecuário 17:20-33.

BRANDÃO, M. \& GAVILANES, M.L. 1997. Cobertura vegetal do município de Pedro Leopoldo, MG: formações vegetais e composição florística. Daphne 7:32-50.

BRASIL. 2008. Instrução Normativa $n^{\circ} 6$, de 23 de setembro de 2008. Anexo 1. Lista oficial das espécies da flora brasileira ameaçada de extinção. Brasília, Ministério do Meio Ambiente.

BURKART, A. 1970. Leguminosas-Faseóleas argentinas de los géneros Mucuna, Dioclea y Camptosema. Darwiniana 16:175-218.

CARVALHO, A.M. 1997. A synopsis of the genus Dalbergia (Fabaceae, Dalbergieae) in Brazil. Brittonia 49:87-109. http://dx.doi.org/10.2307/2807701

CARVALHO-OKANO, R. M. \& LEITÃO-FILHO, H. F. 1985. Revisão do gênero Calopogonium Desv. (LeguminosaeLotoideae) no Brasil. Revista Brasil. Bot. 8:31-46.

COLWELL, R.K., RAHBEK, C. \& GOTELLI , N.C. 2004. The Mid-domain effect and species richness patterns: what have we learned so far? The American Naturalist 163(3): E1-23.

CRIA (Centro de Referência em Informação Ambiental). 2013. species Link. http://splink.cria.org.br/(accessed 13/02/2012)

DRUMMOND, G.M.; MARTINS, C.S.; MACHADO, A.B.M.; SEBAIO, F.A. \& ANTONINI, Y. 2005. Biodiversidade em Minas Gerais: um atlas para sua conservação. Fundação Biodiversitas, Belo Horizonte.

DUTRA, V. F. 2005. Leguminosae Adans. nos campos rupestres do Parque Estadual do Itacolomi, Minas

Gerais, Brasil: florística, preferência por habitat, aspectos reprodutivos e distribuição geográfica. Dissertação de Mestrado, Universidade Federal de Viçosa, Viçosa,

171p. DUTRA, V.F. 2009. Diversidade de Mimosa L.

(Leguminosae) nos campos rupestres de Minas Gerais: taxonomia, distribuição geográfica e filogeografia. Tese de doutorado, Universidade Federal de Viçosa, Viçosa, 280p.

DUTRA, V.F., GARCIA, F.C.P., LIMA, H. C. \& QUEIROZ, L.P. 2008a. Diversidade florística de

Leguminosae Adans. em áreas de campos rupestres. Megadiversidade 4: 105-113.

DUTRA, V.F., GARCIA, F.C.P., LIMA, H. C. 2008 b. Caesalpinioideae (Leguminosae) nos Campos Rupestres do Parque Estadual do Itacolomi, MG, Brasil. Acta Bot. Brasil. 22:547-558. http://dx.doi.org/10.1590/S010233062008000200021

DUTRA, V.F., GARCIA, F.C.P., LIMA, H. C.2008c. Mimosoideae (Leguminosae) nos campos rupestres do Parque Estadual do Itacolomi, Minas Gerais, Brasil. Rodriguésia 59:573-585.

DUTRA, V.F., GARCIA, F.C.P., LIMA, H. 2009. Papilionoideae (Leguminosae) nos Campos Rupestres do Parque Estadual do Itacolomi, MG, Brasil. Acta Bot. Brasil. 23:145-159. http://dx.doi.org/10.1590/S0102$\underline{33062009000100018}$
DUTRA, V.F. \& MORIM, M.P. 2011. Mimosa. In Lista de Espécies da Flora do Brasil. http://floradobrasil.jbrj.gov.br/2011/FB023084 (accessed 13/02/2012)

DWYER, J.D. 1951. The Central American, West Indian and South American species of Copaifera (Caesalpiniaceae). Brittonia 7:143-172. http://dx.doi.org/10.2307/2804703

EISINGER, S.M. 1987. O gênero Indigofera L. (LeguminosaePapilionoideae-Indigofereae) no Rio Grande do Sul. Acta Bot. Brasil. 1:123-140.

FANTZ, P.R. 1980. Flora of Panama. Ann. Missouri Bot. Gard. 67:582-593.

FERNANDES, A. 1996. O táxon Aeschynomene no Brasil. Editora Universidade Federal do Ceará, Fortaleza.

FERREIRA, F.M. \& FORZZA, R. 2009. Florística e caracterização da vegetação da Toca dos Urubus, Baependi, Minas Gerais, Brasil. Biota Neotrop. 9(4):1-18. http://dx.doi.org/10.1590/S1676-06032009000400014

FILARDI, F.L.R. 2011. Machaerium. In Lista de Espécies da Flora do Brasil. http://floradobrasil.jbrj.gov.br/2011/ FB23055 (accessed 13/02/2012)

FILARDI, F.L.R., GARCIA, F.C.P., DUTRA, V.F. \& SÃOTHIAGO, P.S. 2007. Papilionoideae (Leguminosae) do Parque Nacional da Serra da Canastra, Minas Gerais, Brasil. Hoehnea 34:383-408.

FLORES, A.S. 2011. Crotalaria. In Lista de Espécies da Flora do Brasil. http://floradobrasil.jbrj.gov.br/2011/ FB22902 (accessed 13/02/2012)

FLORES, A.S. 2004. Taxonomia, números cromossômicos e química de espécies de Crotalaria L. (LeguminosaePapilionoideae) no Brasil. Tese de doutorado, Universidade Estadual de Campinas, Campinas, $201 \mathrm{p}$.

FORTUNA-PEREZ, A.P. 2010. Zornia. In Catálogo de Plantas e fungos do Brasil vol. 2. (R.C. Forzza et al., eds.). Andrea Jakobsson Estudio: Instituto de Pesquisas Jardim Botânico do Rio de Janeiro, Rio de Janeiro, pp. 1100-1101.

GARCIA, F.C.P. 1998. Relações sistemáticas e fitogeografia do gênero Inga Miller (Leguminosae, Mimosoideae, Ingeae) nas florestas da costa sul e sudeste do Brasil. Tese de doutorado, Universidade Estadual Paulista, Rio Claro, $248 \mathrm{p}$.

GARCIA, F.C.P. \& FERNANDES, J.M. 2013. Inga. In Lista de Espécies da Flora do Brasil. http://floradobrasil.jbrj.gov.br/2011/FB22803 $\quad$ (accessed 13/02/2012)

GENTRY, A.H. 1995. Patterns of diversity and floristic composition in neotropical montane forests. In Biodiversity and Conservation of Neotropical Montane Forests. Proceedings of the Neotropical Montane Forests Biodiversity and Conservation Symposium. (S.P. Churchill et al., eds.). The New York Botanical Garden, New York, p. 103-26.

GIULIETTI, A. M.; HARLEY, R. M.; QUEIROZ, L. P.; WANDERLEY, M. G. L. \& PIRANI, J. R. 2002. Caracterização e endemismos nos Campos rupestres da Cadeia do Espinhaço. In Tópicos atuais em Botânica (T. B. Cavalcanti \& B. M. T. Walter, eds.). Brasília, SBB/ Embrapa, p. 311-318.

GIULIETTI, A.M., MENEZES, N.L., PIRANI, J.R., MEGURO, M. \& WANDERLEY, M.G.L. 1987. Flora da Serra do Cipó: caracterização e lista das espécies. Bol. Bot. Univ. São Paulo 9:1-151. 
GIULIETTI, A. M. \& PIRANI, J.R. 1988. Patterns of geographic distribution of some plant species from the Espinhaço Range, Minas Gerais and Bahia, Brazil. In Proceedings of a Workshop on Neotropical Distribution Patterns (W.R. Heyer \& P.E. Vanzolini, eds.). Academia Brasileira de Ciências, Rio de Janeiro, p.39-67.

GIULIETTI, A.M.; PIRANI, J.R. \& HARLEY, R.M. 1997. Espinhaço Range region, Eastern Brazil. In Centres of plants diversity 3 (S.D. Davis et al., eds). Information Press, Oxford, p. 397-404.

GONTIJO, B.M. 2008. Uma geografia para a Cadeia do Espinhaço. Megadiversidade 4:7-15. GUEDES-BRUNI,

R.R., MORIM, M.P., LIMA, H.C.,

SYLVESTRE, L. da S. 2002. Inventário Florístico. In Manual Metodológico para estudos botânicos na Mata Atlântica (L. da S. Sylvestre \& M.M.T., Rosa, orgs.). Seropédica, Rio de Janeiro, p. 24-49.

HARLEY, R.M. 1995. Introduction. In Flora of the Pico das Almas, Chapada Diamantina, Bahia, Brazil (B.L. Stannard, ed). Royal Botanical Gardens, Kew, p. 1-40.

HARLEY, R.M. 1988. Evolution and distribution of Eriope (Labiatae), and its relatives in Brazil. In Proceedings of a Workshop on Neotropical Distribution Patterns (W.R. Heyer \& P.E. Vanzolini, eds.). Academia Brasileira de Ciências, Rio de Janeiro, p.71-119.

IBGE (Instituto Brasileiro de Geografia e Estatística). 2012.

Manual técnico da vegetação brasileira. Rio de Janeiro. ILDIS. 2011. International Legumes Database \& Information Service. http://www.ildis.org/ (accessed 13/02/2012) IRWIN, H.S. \& BARNEBY, R.C. 1978. Monographic studies in Cassia (Leguminosae-Caesalpinioideae) III. Sections Absus and Grimaldia. Mem. New York Bot. Gard. 30:1-300.

IRWIN, H.S. \& BARNEBY, R.C. 1982. The American Cassiinae - A synoptical revision of Leguminosae Tribe Cassieae subtribe Cassiinae in the New World. Mem. New York Bot. Gard. 35:1-918.

JOLY, C.A., AIDAR, M.P.M., KLINK, C.A., McGRATH, D.G., MOREIRA, A.G., MOUTINHO, P., NEPSTAD, D.C., OLIVEIRA, A. A., POTT, A., RODAL, M.J.N. \& SAMPAIO, E.V.S.B. 1999. Evolution of the Brazilian phytogeography classification systems: implications for biodiversity conservation. Ciência e Cultura 51(5/6):331-368.

LÉON, J. 1966. Central American and West Indian species of Inga (Leguminosae). Annals of the Missouri Botanical Garden 53:265-359.

LEWIS, G.P. 1987. Legumes of Bahia. Royal Botanic Gardens, Kew.

LEWIS, G.P. \& LIMA, M.P.M. 1991. Pseudopiptadenia Rauschert no Brasil (Leguminosae- Mimosoideae). Arquivos do Jardim Botânico do Rio de Janeiro 30:43-67.

LEWIS, G.P., SCHRIRE, B.D., MACKINDER, B.A. \& LOCK, J.M. 2005. Legumes of the World. Kew, Royal Botanic Gardens.

LIMA, H.C. 2000. Leguminosas arbóreas da Mata Atlântica: uma análise da riqueza, padrões de distribuição geográfica e similaridades florísticas em remanescentes florestais do estado do Rio de Janeiro. Tese de doutorado, Universidade Federal do Rio de Janeiro, Rio de Janeiro, 156 p.

LIMA, H.C. 2011a. Dalbergia. In Lista de Espécies da Flora do Brasil. http://floradobrasil.jbrj.gov.br/2011/FB22908 (accessed 13/02/2012)
LIMA, H.C. 2011b. Tachigali. In Lista de Espécies da Flora do Brasil. http://floradobrasil.jbri.gov.br/2011/FB23195 (accessed $13 / 02 / 2012$ )

LIMA, H.C., CORREIA, C.M.B. \& FARIAS, D.S. 1994. Leguminosae. In Reserva Ecológica de Macaé de Cima, Nova Friburgo, RJ: Aspectos florísticos das espécies vasculares, v.1 (M.P.M. Lima \& R.R. Guedes-Bruni, orgs.). Jardim Botânico do Rio de Janeiro, Rio de Janeiro, p.167-228.

LIMA, H.C., QUEIROZ, L.P., MORIM, M.P., SOUZA, V.C., DUTRA, V.F., BORTOLUZZI, R.L.C., IGANCI, J.R.V., FORTUNATO, R.H., VAZ, A.M.S.F., SOUZA, E.R., FILARDI, F.L.R., VALLS, J.F.M., GARCIA, F.C.P., FERNANDES, J.M., MARTINS-DA-SILVA, R.C.V., PEREZ, A.P.F., MANSANO, V.F., MIOTTO, S.T.S., TOZZI, A.M.G.A., MEIRELES, J.E., LIMA, L.C.P., OLIVEIRA, M.L.A.A., FLORES, A.S., TORKE, B.M., PINTO, R.B., LEWIS, G.P., BARROS, M.J.F., RIBEIRO, R.D., SCHÜTZ, R., PENNINGTON, T., KLITGAARD, B.B., RANDO, J.G., SCALON, V.R., CARDOSO, D.B.O.S., COSTA, L.C., SILVA, M.J., MOURA, T.M., BARROS, L.A.V., SILVA, M.C.R., QUEIROZ, R.T., SARTORI, A.L.B. \& CAMARGO, R. 2010a. Fabaceae. In Catálogo de Plantas e fungos do Brasil vol. 2. (R.C. Forzza et al., eds.). Andrea Jakobsson Estudio: Instituto de Pesquisas Jardim Botânico do Rio de Janeiro, Rio de Janeiro, p. 989-1102.

LIMA, L.C.P., GARCIA, F.C.P. \& SARTORI, A.L.B. 2007. Leguminosae nas florestas estacionais do Parque Estadual do Itacolomi, Minas Gerais, Brasil: ervas, arbustos, subarbustos, lianas e trepadeiras. Rodriguésia 58: 331-358.

LIMA, L.C.P., OLIVEIRA, M.L.A.A. \& TOZZI, A.M.G. 2010b. Desmodium . In Catálogo de Plantas e fungos do Brasil vol. 2. (R.C. Forzza et al., eds.). Andrea Jakobsson Estudio: Instituto de Pesquisas Jardim Botânico do Rio de Janeiro, Rio de Janeiro, p. 1029-1030.

LIMA, L.C.P., GARCIA, F.C.P. \& SARTORI, A.L.B. 2010c. As Leguminosas arbóreas das florestas estacionais do Parque Estadual do Itacolomi, Minas Gerais, Brasil. Rodriguésia 61:441-466.

LIMA, M.P.M., GUEDES-BRUNI, R.R., SYLVESTRE, L.S., PESSOA, S.V.A. \& ANDREATA, R.H.P. 1997. Padrões de distribuição geográfica das espécies vasculares da

Reserva Ecológica de Macaé de Cima. In Serra de Macaé de Cima: diversidade florística e conservação em Mata Atlântica (H.C. Lima \& R.R. Guedes-Bruni, eds.). Jardim Botânico, Rio de Janeiro, p.103-123.

LORENZI, H. 1992. Árvores brasileiras: manual de identificação e cultivo de plantas arbóreas nativas do Brasil v1. Plantarum, Nova Odessa.

MANSANO, V.F., PINTO, R.B. \& TORKE, B.M. 2011. Swartzia In Lista de Espécies da Flora do Brasil. http:/floradobrasil.jbri.gov.br/2011/FB23178 (accessed 13/02/2012)

MARÉCHAL, R., MASCHERPA, J. M. \& STAINER, F. 1978. Étude taxonomique d'un groupe complex d'espéces des genres Phaseolus et Vigna (Papilionaceae) sur la base de données morphologiques et polliniques, traitées par l'analyse informatique. Boissiera 28:1-273.

MATTOS, N.F. 1979. O gênero Andira Lam. (LeguminosaePapilionoideae) no Brasil. Acta Amazônica 9:241-266.

MEGURO, M.; PIRANI, J. R.; GIULIETTI, A. M. \& MELLO-SILVA, R. 1994. Phytophysiognomy and composition of the vegetation of Serra do Ambrósio, Minas Gerais, Brazil. Revista Brasil. Bot. 17:149-166. 
MENDONÇA-FILHO, C.V. 1996. Braúna, angico, jacarandá e outras leguminosas de Mata Atlântica: Estação Biológica de Caratinga, Minas Gerais. Fundação Botânica Margaret Mee; Fundação Biodiversitas, Belo Horizonte.

MENDONÇA-FILHO, C.V., TOZZI, A.M.G.A. \& MARTINS, E.R.F. 2007. Revisão taxonômica de Machaerium sect. Oblonga (Benth.) Taub. (Leguminosae, Papilionoideae, Dalbergieae). Rodriguésia 58:283-312.

MENDONÇA, R.C., FELFILI, J.M., WALTER, B.M.T., SILVA JR., M.C., REZENDE, A.V., FILGUEIRAS, T.S. \& NOGUEIRA, P.E. 1998. Flora vascular do cerrado. In Cerrado: Ambiente e Flora. (S.M. Sano \& S.P. Almeida, eds.). Embrapa-CPAC, Planaltina, p.289-539.

MESSIAS, M.C.T.B.; DIAS, S.J.; ROSCHEL, M.B.; SOUSA, H.C. \& MATOS, A.M. 1997. Levantamento florístico das matas e distribuição de algumas espécies endêmicas da área do Parque Estadual do Itacolomi. UFOP/BIRD/IEFPROFLORESTA. Relatório Técnico, Ouro Preto.

MESSIAS, M.C.T.B. \& SOUZA, H.C. 2006. Plano de Manejo do parque Estadual do Itacolomi - Flora. Relatório Final, Ouro Preto.

MILES, L., NEWTON, A.C., DEFRIES, R..S., RAVILIOUS, C., MAY, I., BLYTH, S., KAPOS, V. \& GORDON, J. E. 2006. A global overview of the conservation status of tropical dry forests. Journal of Biogeography 33:491-505. http://dx.doi.org/10.1111/j.1365-2699.2005.01424.

MIOTTO, S.T.S. 1987. Os gêneros Centrosema (DC.) Benth. e Clitoria L. (Leguminosae, Faboideae) no Rio Grande do Sul. Iheringia, série Botânica 36:15-39.

MITTERMEIER, R.A., GIL, P.R., HOFFMANN, M., PILGRIM, J., BROOKS, T., MITTERMEIER, C.G., LAMOREUX, J. \& FONSECA, G.A.B. 2005. Hotspots Revisited: Earth's Biologically Richest and Most Endangered Terrestrial Ecoregions. CEMEX; Agrupación Sierra Madre, Washington.

MORIM, M.P. 2006. Leguminosae arbustivas e arbóreas da floresta atlântica do Parque Nacional do Itatiaia, sudeste do Brasil: padrões de distribuição. Rodriguésia 57:27-45.

MORIM, M.P. \& BARROS, M.J.F. 2011. Senegalia. In Lista de Espécies da Flora do Brasil. Jardim http://floradobrasil.jbrj.gov.br/2011/FB100997 (accessed 13/02/2012)

MULLER, C. 1984. Revisão Taxonômica do gênero Poiretia Vent. (Leguminosae) para o Brasil. Dissertação de Mestrado, Universidade Estadual de Campinas, Campinas, 150p.

NALINI JUNIOR, H.A., GARCIA, M.P.L \& CASTRO, P.T.A. 2006. Plano de Manejo do parque Estadual do Itacolomi - Meio físico. Relatório Final, Ouro Preto.

NUNES, S.R.D.F.S., GARCIA, F.C.P., LIMA, H.C. \& CARVALHO-OKANO, R.M. 2007. Mimosoideae (Leguminosae) arbóreas do Parque Estadual do Rio Doce, Minas Gerais, Brasil: distribuição geográfica e similaridade florística na Floresta Atlântica no Sudeste do Brasil. Rodriguésia 58:403-421.

OLIVEIRA-FILHO, A. T. 2009. Classificação das fitofisionomias da América do Sul cisandina tropical e subtropical: proposta de um novo sistema - prático e flexível - ou uma injeção a mais de caos? Rodriguésia 60(2):237-258.

OLIVEIRA-FILHO, A.T. \& RATTER, J.A. 1995. A study of the origin of central Brazilian forests by the analysis of plant species distribution patterns. Edinburgh J. Bot. 52:141-194.

OLIVEIRA-FILHO, A.T.; VILELAS, E.A.; GAVILANES, M.L.; CARVALHO, D.A. 1994. Comparison of the flora and soils of six areas of Montane Semideciduous Forest in southern Minas Gerais, Brazil. Edinburgh J. Bot. 51:355-389.

PENNINGTON, R.T. 2003. Monograph of Andira (LeguminosaePapilionoideae). Syst. Bot. Monogr. 64: 1-143.

PENNINGTON, R.T., PRADO, D.A. \& PENDRY, C. 2000 Neotropical seasonally dry forests and Pleistocene vegetation changes. Journal of Biogeography 27:261-273.

PENNINGTON, R.T., LAVIN, M., PRADO, D.E., PENDRY, C.A., PELL, S.K. \& BUTTERWORTH, C.A. 2004. Historical climate change and speciation: neotropical seasonally dry forest plants show patterns of both

Tertiary and Quaternary diversification. Philosophical Transactions of the Royal Society of London Series BBiological Sciences 359: 515-538.

PENNINGTON, R.T., RICHARDSON, J.E. \& LAVIN, M. 2006. Insights into the historical construction of speciesrich biomes from dated plant phylogenies, neutral ecological theory and phylogenetic community structure. New Phytologist 172: 605-616.

PENNINGTON, T.D. 1997. The genus Inga: Botany. Royal Botanic Gardens, Kew.

PERON, M.V. 1989. Listagem preliminar da flora fanerogâmica dos Campos Rupestres do Parque Estadual do Itacolomi, Ouro Preto/Mariana, MG. Rodriguésia 41:63-69.

PIRANI, J.R., MELLO-SILVA, R. \& GIULIETTI, A.M. 2003. Flora de Grão-Mogol, Minas Gerais, Brasil. Bol. Bot. Univ. São Paulo 21:1-24.

POSTON, M. E. 1980. Flora of Panama. Ann. Missouri Bot. Gard. 67:582-593.

PRADO, D.E. \& GIBBS, P.E. 1993. Patterns of species distributions in the dry seasonal forests of South America. Ann. Missouri Bot. Gard. 80:902-927.

QUEIROZ, L.P. 1999. Sistemática e filogenia do gênero

Camptosema W.J.Hook. \& Arn. (Leguminosae: Papilionoideae: Phaseoleae). Tese de Doutorado, Universidade de São Paulo, São Paulo, 259p.

QUEIROZ, L.P. 2006. The Brazilian Caatinga: phytogeographical patterns inferred from distribution data of the Leguminosae. In Neotropical Savannas and Seasonally Dry Forests: plant diversity, biogeography, and conservation (R.T. Pennington, G.P. Lewis \& J.A Ratter, eds.). Taylor \& Francis Boca Raton, p.122 -157.

QUEIROZ, L.P. 2008. Re-Establishment, synopsis and new combinations in the genus Bionia Mart. ex Benth. (Leguminosae: Papilionoideae). Neodiversity 3: 13-18.

RANDO,J.G\&PIRANI,J.R.2011.Padrões de distribuição geográfica das espécies de Chamaecrista sect. Chamaecrista ser.

Coriaceae (Benth.) H. S. Irwin \& Barneby, Leguminosae - Caesalpinioideae. Revista Brasil. Bot. 34:499-513. http://dx.doi.org/10.1590/S0100-84042011000400004

RAPINI, A; RIBEIRO, P.L.; LAMBERT, S. \& PIRANI, J.R. 2008. A flora dos campos rupestres da Cadeia do Espinhaço. Megadiversidade 4:16-24.

RIBEIRO, J.F. 1998. Cerrado: Matas de galeria. EmbrapaCPAC, Planaltina.

RUDD, V.E. 1958. A revision of the genus Chaetocalyx. Contributions from the National Herbarium 32:207-245.

RUDD, V.E. 1965. The American species of Ormosia (Leguminosae). Contributions from the National Herbarium 32:278-384.

SANDERS, N.J. \& RAHBEK, C. 2012. The patterns and causes of elevational diversity gradients. Ecography $35: 1-3$. 
SANTOS, M.F.; SERAFIM, H. \& SANTO, P.T. 2011. An analysis of species distribution patterns in the Atlantic Forests of Southeastern Brazil. Edinburgh J. Bot. 68:373-400.

SARTORI, A.L.B. \& TOZZI, A.M.G.A. 1998. As espécies de Machaerium Pers. (Leguminosae-PapilioinoideaeDalbergieae) ocorrentes no Estado de São Paulo. Revista Brasil. Bot. 21:211-246. http://dx.doi.org/10.1590/S0100-84041998000300001

SCALON, V.R. 2007. Revisão Taxonômica do gênero Stryphnodendron Mart. (Leguminosae-Mimosoideae). Tese de doutorado, Universidade de São Paulo, São Paulo, 264p.

SCHRIRE, B.D.; LEWIS, G.P. \& LAVIN, M. 2005. Biogeography of the Leguminosae. In Leguminosae of the world (G.P. Lewis, B. D. Schrire, B. A. Mackinder \& J. M. Lock, eds.). Royal Botanic Gardens, Kew, p. 21-54.

SILVA, L.F.G. 2007. Taxonomia das espécies dos gêneros Tachigali Aubl. e Sclerolobium Vogel (Leguminosae Caesalpinioideae) da Mata Atlântica. Dissertação de Mestrado, Jardim Botânico do Rio de Janeiro, Rio de Janeiro, 65p .

SOUZA, V.C. \& BORTOLUZZI, R.L.C. 2011a. Chamaecrista. In Lista de Espécies da Flora do Brasil. http://floradobrasil.jbri.gov.br/2011/FB22876 (accessed 13/02/2012)
SOUZA, V.C. \& BORTOLUZZI, R.L.C. 2011b. Senna. In Lista de Espécies da Flora do Brasil. http://floradobrasil.jbrj.gov.br/2011/FB23149 (accessed 13/02/2012)

TAMASHIRO, J.Y. 1989. Estudos taxonômicos morfológicos do gênero Piptadenia, sensu Bentham no sudeste do Brasil. Avaliação das modificações taxonômicas recentemente propostas. Dissertação de Mestrado, Universidade Estadual de Campinas, Campinas, 99p.

VAZ, A.M.S.F. 2011. Phanera. In Lista de Espécies da Flora do Brasil. http://floradobrasil.jbrj.gov.br/2011/FB25673 (accessed 13/02/2012)

VAZ, A.M.S.F. \& TOZZI, A.M.G.A. 2003. Bauhinia ser. Cansenia (Leguminosae: Caesalpinioideae) no Brasil. Rodriguésia 54:55-143.

VELOSO, H.P., RANGEL FILHO, A.L. \& LIMA, J.C.A. 1991. Classificação da vegetação brasileira, adaptada a um sistema universal. IBGE, Rio de Janeiro.

ZAPPI, D.C., LUCAS, E., STANNARD, B.L., LUGHADHA, E.N., PIRANI, J.R., QUEIROZ, L.P., ATKINS, S., HIND, D.J.N., GIULIETTI, A.M., HARLEY, R.M. \& CARVALHO, A.M. 2003. Lista das plantas vasculares de Catolés, Chapada Diamantina, Bahia, Brasil. Bol. Bot. Univ. São Paulo 21:345-398.

Received: $14 / 04 / 2013$

Revised: $12 / 12 / 2013$

Accepted: 10/01/2014 